\title{
Proposed need criteria for HEA II-A
}

\author{
Developed by the ACRL Legislation Committee \\ Nancy Kranich, Chair
}

What constitutes a needy college library?

$\mathbf{T}$ he Higher Education Act is due for reauthorization in this Congress. In the past, three parts of Title II were funded: Part A, College Library Resources Program; Part B, Training and Research and Demonstration Projects; and Part C, Strengthening Research Library Resources. A fourth part was proposed last year to encourage the use and development of new technologies to enhance resource sharing capabilities of academic libraries.

Over the past year, the ACRL Legislation Committee has focused on Title II-A. For two years, this program has not had funding. In the previous year, it allotted only $\$ 890$ per institution. The Congress has indicated its reluctance to continue the program unless its purpose is to target needy libraries through a simple and workable formula. Because the Committee feels strongly that a program for academic libraries is important, it has worked on developing the need criteria that the Congress has requested.

Last year, two bills were introduced into Congress that suggested need criteria for Title II-A. These criteria were proposed without wide input from the profession. Because many college librarians criticized the criteria, the Congress asked the library community to recommend appropriate measures of need.

Accordingly, the ACRL Legislation Committee has reviewed the extensive background materials on the program. Working from earlier proposals and suggestions from the library community, the Committee tried to establish a working definition of a "needy" academic library. It also tried to iden- tify libraries considered "needy" in order to evaluate what criteria described them as such.

All possible criteria were then evaluated through various statistical analyses of the 1982 NCES HEGIS tapes for academic libraries. While no evidence was conclusive in regard to a measure of neediness, some indicators did appear to be both descriptive and relevant. With the results of the analyses, the Committee prepared a recommendation for need criteria and for other Title II-A amendments and forwarded them to the ACRL Board and to the ALA Legislation Committee at the ALA Midwinter meeting in Washington.

The proposed need criteria and changes to the II-A program were presented as follows:

- Funding should be available to those libraries which rank below the norm when scored for both "materials expenditures/FTE student" and "volumes held/FTE student." Libraries would be compared to like institutions according to the classification designated by HEGIS-2 year, 4 year, and university.

- Maintenance of effort provision in relation to materials expenditures must be assured as designated in the current law. A graduated amount between $\$ 2,000$ and $\$ 10,000$ would be awarded to needy libraries annually, based on an institution's FTE enrollment range.

- Definitions of materials expenditures, volumes, institutions, and enrollment would be based on those used by the National Center for Education Statistics for HEGIS reports.

- Libraries would be expected to designate how they plan to use the funds on the grant application 
forms and to report on their use after the grant period in conjunction with their final financial reports.

- Research libraries receiving support from the HEA II-C program would be ineligible for II-A funds in that fiscal year.

- An appropriate organization would evaluate the effectiveness of the program after two years.

While the criteria suggested may not satisfy everyone's definition of a needy library, they are relevant to the purpose of the program (expanding college library resources) and constitute statistically valid tests of need. Both the ACRL Board and the ALA Legislation Committee endorsed the proposed criteria. In addition, they passed a resolution recommending reauthorization of the Higher Education Act (with suggested amendments for II-A and inclusion of a new program for the use and development of new technologies). The ALA Council has also endorsed the resolution. Now the entire library community must rally behind the proposal in order to demonstrate the unity necessary to reestablish the HEA II-A program and get it funded in the future. Because it is the only federal program that assists college libraries exclusively and because so many college libraries are truly needy, it is crucial that librarians recognize the value of supporting and encouraging reauthorization and amendment of Title II-A along with all other programs included in the Higher Education Act.

\section{ACRL guidelines for publications support requests}

These guidelines were developed by the ACRL Publications Committee and approved by the ACRL Board of Directors at their meeting of January 8,1985 .

1. Publication support requests from ACRL sections or other groups will be referred to the Publications Committee by the Budget and Finance Committee for a recommendation.

2. Financial support for such publications will be viewed as a special project expense.

3. ACRL shall be offered the first right of refusal to publish any items produced with the assistance of ACRL special project funds.

4. If ACRL chooses not to publish as outlined in 3 above, the ACRL Executive Director shall be involved in the negotiations with an outside publisher to attempt to recoup investment expenses, or to get agreement regarding the type of acknowledgement that will be made of ACRL support.

5 . When publication support requests are received at ACRL headquarters, staff shall automatically refer the requests to the Publications Committee as well as to the Budget and Finance Committee.

\section{Section newsletters policy}

This policy was developed jointly by the ACRL Budget and Finance Committee and the ACRL Publications Committee. It was approved by the ACRL Board of Directors at their meeting of January 8,1985 .

The following points constitute the above committee's deliberations regarding Section Newsletters.

1. The ownership statement for section newsletters will be designed such that it will include the name of the section, name of the division (ACRL), ALA, and other essential elements as described in: "ALA Periodicals: Essential Elements," an ALA Publications Committee document of July 10, 1982.

2. Each section publishing a newsletter will provide a written report to the Publications Committee once a year.

3. Each section may, under normal circumstances, expect to receive funding for either two newsletters a year, each of up to four sheets (8 pages), or one newsletter a year, of up to eight sheets (16 pages).

4. Sections shall be responsible for submitting camera-ready copy to ACRL Headquarters, according to specifications prepared by the ACRL Headquarters staff. Headquarters staff shall have the responsibility for getting the newsletters reproduced and mailed out by first class mail within two weeks of receipt of the final camera-ready copy.

5. Each section shall be provided with a $10 \%$ overrun of copies for the section to distribute at its own cost and discretion. If a section requires more than a $10 \%$ overrun of its membership size, additional copies will be made available to the section at cost. The section can then decide who it will charge.

6. In light of 5 above, ACRL will not establish a policy on newsletter subscriptions to nonmembers.

7. If a section believes that the content of its newsletter requires that the newsletter be more extensive than as outlined in 3 above, the section can request special support as part of the section's normal budget request to the Budget and Finance Committee. The request would be viewed as a special program activity of the section, and would be reviewed by the Publications Committee. 


\section{For the researcher}

who needs the answer now

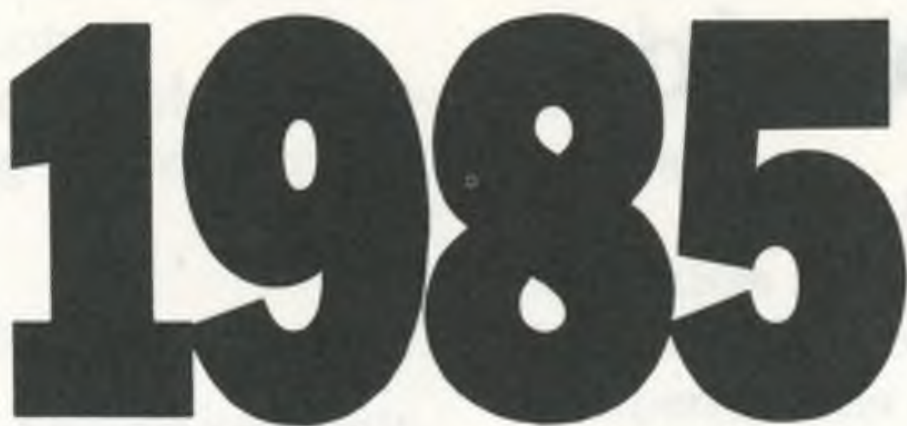

brings the most important new reference work since NUCMC*

*National Union Catalog of Manuscript Collections (NUCMC) was first published in 1959.

\section{The National Inventory of Documentary Sources in the United States}

For the researcher who values his time and is frustrated by the delays and difficulties of finding out what is in a collection.

For the researcher who wants to cover every possible source of documents - without moving out of the library

For the researcher who needs to know in detail the contents of a collection.

The National Inventory brings together finding aids, lists, indexes, and catalogs to thousands of collections, reproduces them on microfiche and indexes them in an easy-to-use names and subject index.

The National Inventory is continuously being added to.

It already includes finding aids to collections in:

The National Archives, Library of Congress, Smithsonian Institution, Presidential Libraries.

Also covered are collections in State Archives, State Historical Societies

Universities, Public Libraries, and in many other repositories.

For descriptive brochures, prices and sample microfiche, please call Linda Fox on (201) 692-1801

\section{Chadwyck-Healey Inc.}

623 Martense Avenue, Teaneck, NJ 07666 